ISSN: 2586-6036 @ 2020 JWMAP. http://www.welfareconvergence.or.kr doi: http://dx.doi.org/10.13106/jwmap.2020.Vol3.no1.1.

\title{
Ownership Concentration, Board Education Diversity, and Environmental Accounting Disclosure in Kenyan Listed Firms. Moderation Approach
}

\author{
${ }^{1}$ John Kipngetich TARUS \\ 1. First Author \& Corresponding Author Dr. Department of Accounting and Finance, Moi University, Kenya, \\ Email: jktarus47@gmail.com
}

Received: February 18, 2020. Revised: February 28, 2020. Accepted: March 10, 2020

\begin{abstract}
The purpose of this study was to examine the moderating effect of board education diversity on the relationship between ownership concentration and environmental accounting disclosure. The study was driven by stakeholder's theory. The longitudinal research design was adopted in the study. The study targeted 27 listed firms from 2008 to 2017. Panel regression analysis results indicated ownership concentration $(\beta=-.131, \rho<.05)$ had a negative and significant effect on environmental disclosure in Kenyan firms. However, Board education diversity positively moderated the relationship between ownership concentration $(\beta=.138, \rho<.05)$ and environmental accounting disclosure. Thus, board education diversity is an enhancing moderator in the relationship between ownership concentration and environmental accounting disclosure. The findings validate stakeholder theory's proposition. The study recommends that firms listed in the NSE ought to diffuse ownership concentration, and their boards should be well educated and experienced to enhance environmental accounting disclosure.
\end{abstract}

Keywords: Board Education Diversity, Environmental Accounting Disclosure, Ownership Concentration.

JEL Classification Code: E22, F24, G20, G21, G29.

\section{Introduction}

The trend in environmental awareness has led to a rising demand for environmental accountability by organizations. Although corporate disclosures play a critical role in mitigating information asymmetry, corporate disclosure literature has documented significant disclosure variations rates across nations and corporations (Demir \& Bahadir, 2014; Aljifri et al., 2014). The significant variations in the extent of disclosure across companies globally promote researchers to look at the variables behind this variation. It is therefore essential for a company to know the environmental accounting disclosure determinations such as the firm's specific attributes. Over the past few decades (Al-Janadi et al., 2012), the diversity of managers and board members has been one of the most important corporate governance issues; thus, corporate disclosure. Since boards of directors are accountable for disclosure procedures and need to be conscious that appropriate disclosure of data is crucial to assess investment possibilities and risks (Al-Janadi et al., 2012), it is anticipated that various boards will disclose value-relevant information to stakeholders in order to enhance decisionmaking processes.

Another characteristic included in previous research is the capacity of the board, too based on the assumption that expertise and abilities guarantee better monitoring, thus greater disclosure. Previous studies indicate that board capacity could be evaluated using the following features: Knowledge and abilities to monitor an organization 
appropriately (Nicholson \& Kiel, 2004), legitimacy and the ability to connect the company with key stakeholders and other key parties (Ong \& Wan, 2008), professional accounting and financial knowledge to report in a more simple way, experience measured from a variety of backgrounds and management of other unconnected firms (Westphal \& Milton, 2010), hoping that board monitoring and decision-making should be improved. According to previous results (Haniffa \& Cooke, 2002; Chiang \& He, 2010), board members with higher education degrees are anticipated to have better general knowledge, while those in dual roles are presumed to have better business understanding and experience, and thus should be able to guarantee more disclosure of corporate information.

Professional knowledge has proved to provide better oversight, fair and adequate disclosure of corporate information. However, board diversity's impact on disclosure practices still remain unexplored and requires further studies as a strong disclosure approach is critical to meeting the data requirements of its shareholders and thus reducing information asymmetries on capital markets (Haniffa \& Cooke, 2002; Chiang \& He, 2010). This is a relevant issue for the understanding of the benefits of board diversity since the previous literature generally assumes that voluntary disclosures help to enhancing transparency while improving firm results and market efficiency. However, despite the fact that social accounting and reporting is a new phenomenon and the absence of any compulsory regulation for this disclosure in Kenya, businesses are willingly involved in reporting on several social responsibility operations in their annual financial reports and it appears that businesses have made significant progress beyond literature. While many studies on corporate social responsibility (CSR) have been conducted on social and environmental accounting and reporting in particular, few have been performed to determine the moderating impact of board education diversity on the link between ownership concentration and environmental accounting disclosure in the Nairobi security exchange, Kenya.

\section{Theoretical Framework}

The study was guided by Stakeholder theory which has been widely employed in accounting literature as providing strong justification for both corporate social and environmental disclosure practices and corporate governance mechanisms. The theory of stakeholders includes recognizing and identifying the connection between the conduct of the company and its stakeholders' effect (Ansoff, 1965). Therefore, the corporation's continued existence needs stakeholders support and its approval must be sought and the activities of the corporation are adjusted to obtain that approval. The stronger the stakeholders the more the company adapts (Gray, et al., 1995). The organization has many stakeholders, which is why it owes accountability to all its stakeholders, referring to the broad spectrum of duties allocated to corporate decision-makers (Gray et al., 1996). However, this connection can be managed by offering more data through voluntary social and environmental reporting, supporting and approving stakeholders.

The stakeholder theory's primary benefit is to provide a means to deal with various stakeholders with multiple conflicting interests. It was asserted that the satisfaction of the various stakeholders' interests is accomplished through system-centered theory (Freeman, 1984). In the context of corporate social responsibility research, stakeholder theory offered a new perspective by suggesting that shareholder requirements cannot be met without meeting other stakeholders' needs (Foster \& Jonker, 2005; Jamali, 2008). The stakeholder theory, therefore, offers a helpful structure for evaluating the operations of corporate social and environmental reporting (Snider et al., 2003). The stakeholder theory's basic proposition is that the result of the effective leadership of the company's interactions with stakeholders determines the achievement of the firm (Elijido-Ten, 2004). In this situation, the organization of interest identifies the stakeholders by a perceived strategic need to handle specific interactions in order to attain their goals (Uwuigbe, 2011). The theory supports the idea that the behavior of various stakeholder groups is what encourages management to match corporate needs with their surroundings (Nassr, 2004). The stakeholder theory management branch offers a structure for analyzing CSED in an organization-centric manner. The achievement of handling stakeholders properly using CSED through the release of accountability is probably some type of organizational legitimacy (Van Der Laan, 2009). According to stakeholder theory, the economic performance of a firm also has a positive impact on voluntary environmental and social disclosure (Cormier \& Magnan, 2003; Ho \& Taylor, 2007) and social responsibility investment (Cho and Patten, 2007).

\subsection{Literature review}


Ownership concentration is defined as the ownership structure and the proportion of the company's shares that are owned by a given number of the largest shareholders (Sanda et al., 2005). According to Brammer \& Pavelin (2006), shareholders have little direct power over executives in the event of ownership dispersion and are therefore unable to monitor management efficiently and a consequent degree of information asymmetry. This situation brings an adverse investor reaction, provides an incentive for a firm to disclose environmental information to shareholders (Brammer \& Pavelin, 2006; Ullmann, 1985). Alternatively, ownership concentration, which is associated with fewer agency conflicts, decreases the likelihood of voluntary disclosure. In addition, substantial shareholders may represent a key stakeholder group who have power (O'Sullivan et al., 2008) and therefore can obtain the required information from alternative sources other than corporate disclosure (Berthelot et al., 2003). Similarly, Cormier et al., (2005) asserted that close-held ownership is not expected to respond to public disclosure as the dominant shareholders typically have access to the data they need.

Companies can decide to disclose environmental accounting if the benefits exceed the costs, even if that means neglecting the best interest of the minority shareholders (Jaggi et al., 2009). It is envisaged that companies with a low percentage of concentrated ownership may not be likely to report voluntary information because they are no interested family owners to maximize their own private benefits. Jiang et al. (2011) examined the effect of ownership concentration and disclosure of data asymmetry among New Zealand companies. Their results demonstrated a positive effect of ownership concentration along with the adverse effect on information asymmetry from discretionary disclosure. Reeb \& Zhao (2013) also evaluated the associations between board members' education, experience, and communication, quality of disclosure, and asymmetry of data. Their findings demonstrate an inverse relationship between board members ' education, experience and communication and information asymmetry. In addition, Dai $e t$ al., (2013) explored how information asymmetry and ownership of mutual funds influenced the earnings management of the listed companies. The research results showed that decreasing the asymmetry of data enhanced the earnings management conduct of companies. Furthermore, they also discovered that the long-term mutual funds, compared with the short-term mutual funds, increased the quality of income by taking on a monitoring function. However, by evaluating data accuracy, Han et al., (2014) noted that managerial ownership was favorably correlated with the public and personal data accuracy of economic analysts, mainly consistent with the managerial equity ownership alignment perspective.

Previous researches document that high level of education among directors on the boards results in a greater ability to adopt new ideas and to accept innovations (Guthrie et al., 1990; Wally \& Baum 1994; Miller et al., 2009, a broader view and larger breadth of understanding (Post et al., 2011). More diverse boards possess more diverse knowledge bases and the perspectives necessary to develop and evaluate solutions to complex problems (Milliken \& Martins 1996; Van Der Walt et al., 2003; Van der Walt et al., 2006). An educated director can have a broader perspective and superior pattern of thinking and, thus, is more likely to understand the wider interests of various stakeholders (Welford 2007).

Diversity in boardrooms has received a great deal of attention in recent years for both regulators and academics. International organizations have considered diversity as an important goal in most of the reforms of governance codes (Hafsi \& Turgut, 2013). The Securities and Exchange Commission has introduced particular regulations in the United States that regulate the disclosure of listed companies and how board diversity is regarded in the nominee selection process (SEC Release 33-9089 published on 16 December 2009). However, Hafsi \& Turgut (2013) play a crucial role in understanding the variety of boards. Examining the impact of two-dimensional board diversity on the social performance of companies listed on S\&P 500, they find that board diversity is statistically important and favorably linked to social disclosures, and that board diversity does not have a significant impact on social disclosures.

Furthermore, this research first assumes that board diversity characteristics are of equal significance and then attaches unequal significance to the measurement of board diversity and board diversity indices. Previous studies also document a favorable connection between disclosure (such as social and economic disclosure or voluntary disclosure) and board of manager's demographic characteristics such as gender diversity (Bear et al., 2010; Fernandez-Feijoo et al., 2014; Post et al., 2011) and diversity of education (Akhtaruddin \& Abdur Rouf, 2012). Board members with distinct educational levels are important for corporate efficiency as it enhances the ability of managers to process data and skills to acknowledge new views and abstractions (Hsu et al., 2013). It also enhances the social relationship and affinity of corporate board members with other industry participants (Nielsen, 2010). Wallace and Cooke (1990) 
argued that managers with a background in accounting and business education could generate a wider amount of disclosure to improve management's corporate image and credibility.

The primary goal of the present study is to empirically examine the moderating impact of board education diversity on the connection between ownership concentration and disclosures of environmental accounting in Kenya. The major contribution of the present research is that it is the first study to tackle corporate environmental disclosures empirically, to the best of my understanding, in line with the framework of international accounting standards. However, in this respect, the study is expected to fill an existing gap in corporate environmental disclosure literature. Consequently, it intends to systematically extend prior research within a Kenya context and to overcome the limitations inherent in prior research. The current study contributes to two streams of literature, the disclosure literature, and ownership structure literature, by providing updated documentary and empirical evidence on the relationship between ownership structure literature and environmental accounting disclosure practices in the annual reports of Kenya companies. Based on the theoretical framework specifically on stakeholder theory, ownership concentration is crucial in predicting or signaling firms financial report quality. Furthermore, numerous studies based on literature have given some proof on the link between ownership concentration and disclosure of environmental accounting. Thus, the study hypothesized that:

Ho: $\quad$ Board education diversity has no significant moderating effect on the relationship between ownership concentration and environmental accounting disclosure of listed firms in Nairobi Securities Exchange.

\section{Methodology}

The study was based on a positivist approach in longitudinal research design in attempting to confirm formulated hypotheses in order to elucidate the current scenario (Bechhofer and Paterson, 2008). The study used secondary data collected from the audited annual financial reports from 67 listed firms at the Nairobi Securities Exchange from 2008 to 2017. The period of the empirical analysis was ten years from 2008 to 2017. The plausible explanation was that these firms are likely to pollute the environment. Therefore, the study's inclusion criteria were the 27 listed firms from 2008 to 2017.

Data was sourced from capital market authority or downloaded from http://www.cmarcp.or.ke/index.php/financialreports-accounts, company website, and http://africanfinancials.com. The data collection instrument used in this study is a content/document analysis guide. Environmental disclosure content analysis involves the construction of a classification scheme and establishing a set of decision rules for coding, measuring and recording the data being examined (Milne \& Adler, 1999). A checklist of environmental disclosure items listed by the disclosure category is constructed to capture corporate environmental disclosure practices in annual reports.

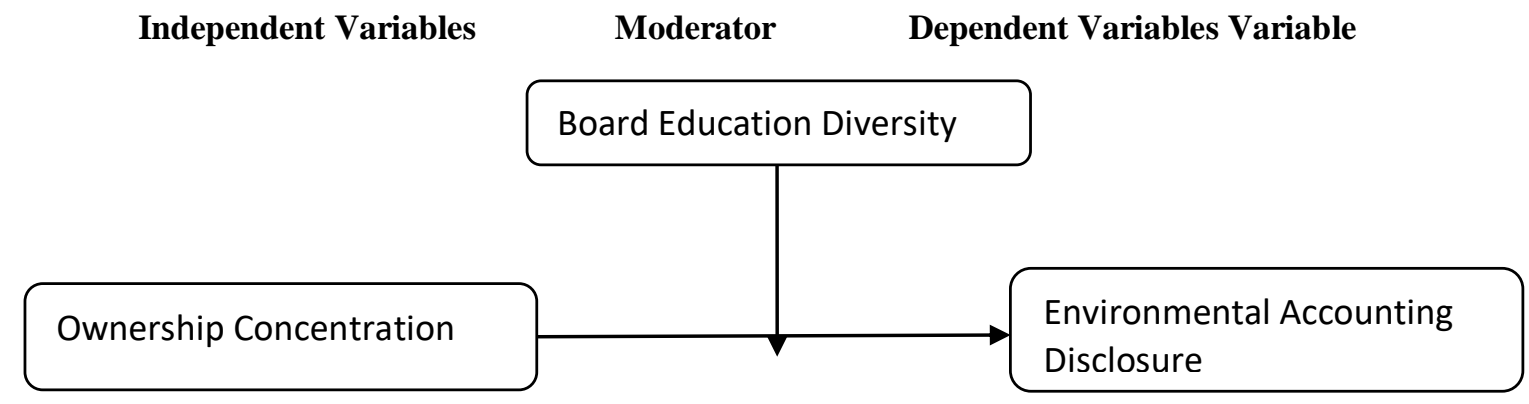

Source: The authors (2019)

Figure 1: Conceptual Framework 
The checklist consists of various segments displaying the distinct categories or regions to which each data about environmental disclosure belongs. A preliminary checklist that contains the expected environmental accounting information items is prepared based on prior studies that have extensively examined environmental disclosure practices (Burritt, 1997; Clarkson et al., 2008; Cormier \& Magnan, 2003; Cormier et al., 2011; Cormier et al., 2005). The checklist is then adapted to match the best practices as outlined in the Global Reporting Initiative rules and suggestions (GRI, 2006). Environmental disclosure quantity is coded by identifying each environmental information item in the annual report with one of the checklist items using predetermined decision rules. This procedure enabled the revealed data to be codified into predefined classifications. Dichotomous results are used to examine the existence or lack of the various items in the checklist using binary codes. The study assumes that board education diversity moderates the relationship between ownership concentration and environmental accounting disclosure. This interaction is diagrammatically depicted in figure 1 .

\section{Findings}

This section presents the findings and discussions of the results. Descriptive statistics are provided in Table 1 for the dependent, independent and test factors. Using a scoring system to develop an EDI, consistent with previous study findings, our results indicate that the mean value of environmental accounting disclosure ranged from a minimum of .060 to a maximum of .870 . The average value for environmental accounting disclosure was. 526 . Although the level of environmental accounting reported during the period 2008 to 2017 is low on an aggregate basis, the extent of environmental disclosure has increased between 2008 and 2017 as well as the number of Kenyan companies disclosing environmental information. Indeed, despite the low average value of the environmental disclosure index, it has positively evolved, both overall and in each industry. Therefore, we can assert that the Keya firms' environmental reporting practices have improved over the studied period of time, although their level of environmental disclosure still lags behind those of other European countries, such as Spain. Ownership concentration was at a mean of 32.636 with a minimum of .000 and a maximum of 97.540 indicating that on average the five highest shareholders of the firms had 32.6\% shareholding. From table 1, the findings also revealed that although ownership concentration had a negative $(\mathrm{r}=-.494)$ correlation with environmental accounting disclosure, the relationship was significant, $\mathrm{p}<.01$. In addition, board education had a positive and significant correlation with environmental accounting disclosure $(\mathrm{r}=.302)$.

Table 2: Correlation Results

\begin{tabular}{lccccccc}
\hline Stats & Min & Max & Mean & Sd & EAD & OC & BED \\
\hline EAD & .060 & .870 & .526 & .215 & 1 & \\
BED & 2.360 & 5.000 & 4.188 & .521 & $-.494 * *$ & 1 \\
OC & .000 & 97.540 & 32.636 & 24.736 & $.302 * *$ & $-.427 * *$ & 1 \\
\hline ** Correlation is significant at the .01 level (2-tailed). \\
* Correlation is significant at the .05 level (2-tailed).
\end{tabular}

Source: (Field data, 2019)

\subsection{Hypothesis testing}

Hypothesis $\mathrm{H}_{0}$ indicated that the board education diversity has no significant moderating impact on the link between ownership concentration and disclosure of environmental accounting of selected listed companies in NSE. The findings showed that board education diversity had a negative and significant moderating impact on the association 
between ownership concentration and disclosure of environmental accounting $(\beta=-.131 ; \rho<.05)$. The Ho5a assumption was therefore rejected. This means that board education diversity enhances the association between ownership concentration and disclosure of environmental accounting. Thus, under higher Board, education diversity ownership concentration strongly affects environmental accounting disclosure $(\beta=.138 ; \rho<.05)$. In line with the results, Hafsi \& Turgut (2013) explained that board diversity is statistically significant and linked positively to environmental disclosures.

Table 3: Hierarchical Regression for Testing Moderating Effect Board Diversity

\begin{tabular}{|c|c|c|c|c|c|c|c|c|c|}
\hline \multirow[b]{2}{*}{ EAD } & \multicolumn{3}{|c|}{ Model 1} & \multicolumn{3}{|c|}{ Model 2} & \multicolumn{3}{|c|}{ Model 3} \\
\hline & Coef. & $\begin{array}{l}\text { Std. } \\
\text { Err. }\end{array}$ & $P>t$ & Coef. & $\begin{array}{l}\text { Std. } \\
\text { Err. }\end{array}$ & $P>t$ & Coef. & $\begin{array}{l}\text { Std. } \\
\text { Err. }\end{array}$ & $P>t$ \\
\hline $\mathrm{OC}$ & -.131 & .054 & .015 & -.104 & .056 & .063 & -.313 & .154 & .044 \\
\hline BED & -.190 & .182 & .299 & .594 & .348 & .090 & .050 & .511 & .922 \\
\hline OC_BED & & & & -1.124 & .577 & .053 & .138 & .095 & .048 \\
\hline _cons & & & & & & & -.301 & .808 & .710 \\
\hline sigma_u & .310 & & & .313 & & & .316 & & \\
\hline sigma_e & .759 & & & .756 & & & .754 & & \\
\hline Rho & .143 & & & .147 & & & .150 & & \\
\hline $\begin{array}{l}\text { R-sq: } \\
\text { within }\end{array}$ & .358 & & & .388 & & & .422 & & \\
\hline R-sq $\Delta$ & & & & .031 & & & .034 & & \\
\hline$F(1,242)$ & 5.960 & & & 4.460 & & & 3.690 & & \\
\hline Prob $>$ F & .015 & & & .013 & & & .013 & & \\
\hline \multicolumn{10}{|c|}{ Housman test } \\
\hline $\operatorname{chi2(6)}$ & 4.001 & & & 6.010 & & & 6.930 & & \\
\hline Prob>chi2 & .020 & & & .000 & & & .000 & & \\
\hline
\end{tabular}

\subsection{Nature of Moderation}

As concerns the moderating effect, Figure 2 reveals that at lower levels of ownership concentration, environmental accounting is higher for firms with high board education diversity compared to those with low board education diversity. However, at a high level of ownership concentration, environmental accounting disclosure increases more for firms with high board education diversity compared to those with low board education diversity as indicated by the steepness of the slopes. Therefore, the hypothesis was not supported and it was concluded that board education diversity is an enhancing moderator (strengthens the relationship). 


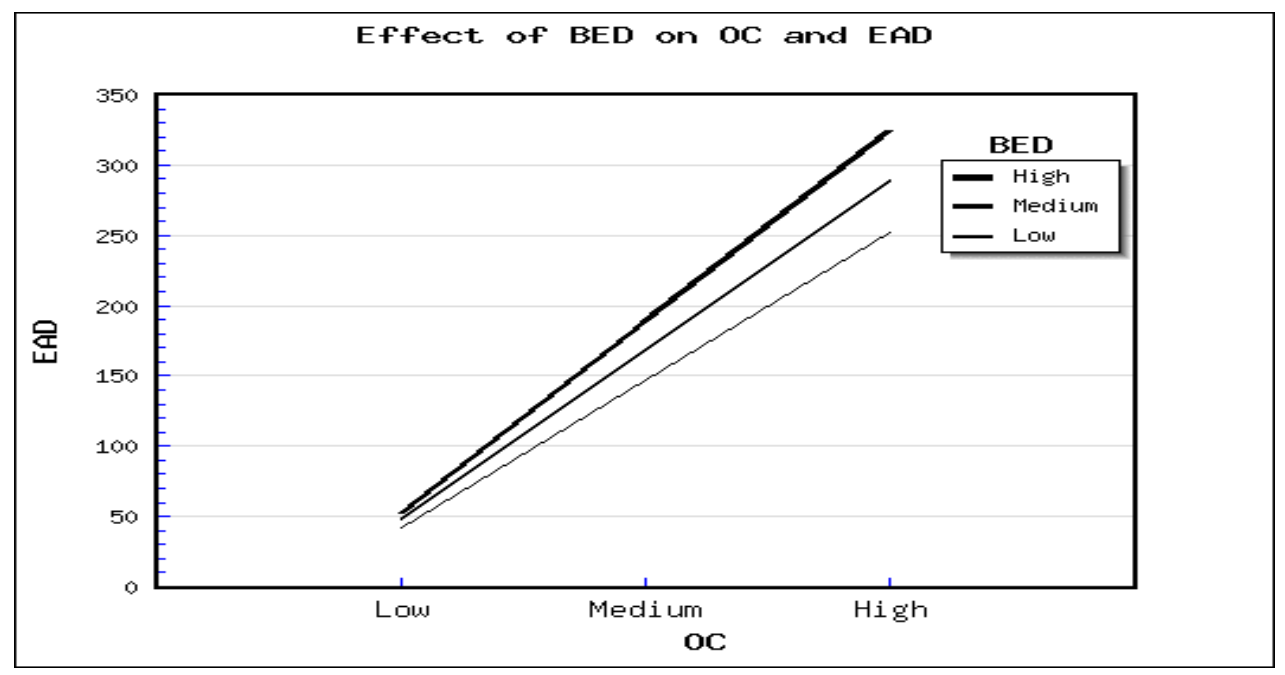

Source: The authors (2019)

Figure 2: Modgraph of board education diversity on the relationship between ownership concentration and environment accounting disclosure

\section{Conclusion and Recommendations}

The research found that board education diversity positively moderates the relationship between ownership concentration and environmental accounting disclosure among the selected listed companies in NSE. The incidence of ownership by the five biggest shareholders may be correlated with reduced rates of disclosure of environmental accounting. The findings indicate that companies do not act more in environmental protection. There is, therefore, an asymmetry of data regarding environmental disclosure. In addition, the cost/benefit trade resulting from the public disclosure of personal data is likely to be addressed as the benefit is distributed among many investors (Cormier \& Magnan, 1999). In contrast, closely-held companies, (with the absence of non-managerial or outside shareholders) tend to have a lesser need for environmental information. More importantly, a significant amount of funding is required for environmental disclosure. In addition, the price of the disclosure may well outweigh the advantage to some firms, particularly smaller firms and closely-held firms. These businesses rarely spend large amounts in operations linked to social or environmental issues. Furthermore, close ownership and dominant shareholders typically have access to the data they need (Cormier et al., 2005). Management is therefore not sensitive to wider public disclosures of the environment.

The theoretical developed by the current study is the first to use the moderation effect of board education on the link between ownership concentration and disclosure of environmental accounting. However, the results elaborated that having highly educated board members in the firms improve corporate environmental accounting disclosure. The research, however, depended strongly on annual audited financial reports, thereby excluding other sources of environmental disclosure data. Despite these constraints, the findings of this study may support other research findings and provide a foundation for future studies.

\section{References}

Akhtaruddin, M. and Rouf, D., 2012. Corporate governance, cultural factors and voluntary disclosure: Evidence from selected companies in Bangladesh. Corporate Governance, Cultural Factors and Voluntary Disclosure: Evidence 
from Selected Companies in Bangladesh (June 1, 2012). Corporate Board: Role, Duties \& Composition, 8(1), pp.46-58.

Al-Janadi, Y., Rahman, R.A. and Omar, N.H., 2012. The level of voluntary disclosure practices among public listed companies in Saudi Arabia and the UAE: Using a modified voluntary disclosure index. International Journal of disclosure and Governance, 9(2), pp.181-201.

Aljifri, K., Alzarouni, A., Ng, C. and Tahir, M.I., 2014. The association between firm characteristics and corporate financial disclosures: evidence from UAE companies. The International Journal of Business and Finance Research, 8(2), pp.101-123.

Ansoff, H. I. Corporate Strategy, McGraw-Hill, New York, 1965.

Baron, R.M. and Kenny, D.A., 1986. The moderator-mediator variable distinction in social psychological research: Conceptual, strategic, and statistical considerations. Journal of personality and social psychology, 51(6), p.1173.

Bear, S., Rahman, N. and Post, C., 2010. The impact of board diversity and gender composition on corporate social responsibility and firm reputation. Journal of Business Ethics, 97(2), pp.207-221.

Bechhofer, F. and Paterson, L., 2012. Principles of research design in the social sciences. Routledge.

Berthelot, S., Cormier, D. and Magnan, M., 2003. ENVIRONMENTAL, DISCLOSURE RESEARCHI: FEVIEW AND SYNTHESIS. Journal of Accounting Literature, 22, pp.1-44.

Brammer, S., Brooks, C. and Pavelin, S., 2006. Corporate social performance and stock returns: UK evidence from disaggregate measures. Financial management, 35(3), pp.97-116.

Burritt, R.L. and Welch, S., 1997. Australian commonwealth entities: an analysis of their environmental disclosures. Abacus, 33(1), pp.69-87.

Chiang, H.T. and He, L.J., 2010. Board supervision capability and information transparency. Corporate Governance: An International Review, 18(1), pp.18-31.

Cho, C.H. and Patten, D.M., 2007. The role of environmental disclosures as tools of legitimacy: A research note. Accounting, organizations and society, 32(7-8), pp.639-647.

Clarkson, P.M., Li, Y., Richardson, G.D. and Vasvari, F.P., 2008. Revisiting the relation between environmental performance and environmental disclosure: An empirical analysis. Accounting, organizations and society, 33(45), pp.303-327.

Cormier, D. and Magnan, M., 1999. Corporate environmental disclosure strategies: determinants, costs and benefits. Journal of Accounting, Auditing \& Finance, 14(4), pp.429-451.

Cormier, D. and Magnan, M., 2003. Environmental reporting management: a continental European perspective. Journal of Accounting and public Policy, 22(1), pp.43-62.

Cormier, D., Ledoux, M.J. and Magnan, M., 2011. The informational contribution of social and environmental disclosures for investors. Management Decision, 49(8), pp.1276-1304.

Cormier, D., Magnan, M. and Van Velthoven, B., 2005. Environmental disclosure quality in large German companies: economic incentives, public pressures or institutional conditions?. European accounting review, 14(1), pp.3-39.

Dai, Y., Kong, D. and Wang, L., 2013. Information asymmetry, mutual funds and earnings management: Evidence from China. China Journal of Accounting Research, 6(3), pp.187-209.

Demir, V. and Bahadir, O., 2014. An investigation of compliance with International Financial Reporting Standards by listed companies in Turkey. Accounting and Management Information Systems, 13(1), p.4.

Dragomir, V.D., 2010. Environmentally sensitive disclosures and financial performance in a European setting. Journal of Accounting \& Organizational Change, 6(3), pp.359-388.

Elijido-Ten, E., 2004, July. Determinants of environmental disclosures in a developing country: an application of the stakeholder theory. In Fourth Asia Pacific interdisciplinary research in accounting conference, Singapore (pp. 46).

Ezhilarasi, G. and Kabra, K.C., 2017. Factors influencing environmental disclosures: Evidence from India. IUP Journal of Accounting Research \& Audit Practices, 16(1), p.7.

Fernandez-Feijoo, B., Romero, S. and Ruiz-Blanco, S., 2014. Women on boards: do they affect sustainability reporting?. Corporate Social Responsibility and Environmental Management, 21(6), pp.351-364.

Foster, D. and Jonker, J., 2005. Stakeholder relationships: the dialogue of engagement. Corporate Governance: The international journal of business in society, 5(5), pp.51-57.

Freeman, R.E., 1984. Strategic Management: A Stakeholder Approach (Boston: Pitman, 1984). Jennings, in the article cited above, quotes Freeman and gives additional information concerning the influence of his work.

Gray, R., Kouhy, R. and Lavers, S., 1995. Corporate social and environmental reporting: a review of the literature and a longitudinal study of UK disclosure. Accounting, Auditing \& Accountability Journal, 8(2), pp.47-77.

Gray, R., Owen, D. and Adams, C., 1996. Accounting \& accountability: changes and challenges in corporate social and environmental reporting. Prentice Hall. 
Güner, A.B., Malmendier, U. and Tate, G., 2008. Financial expertise of directors. Journal of financial Economics, 88(2), pp.323-354.

Guthrie, J. and Parker, L.D., 1990. Corporate social disclosure practice: a comparative international analysis. Advances in public interest accounting, 3, pp.159-175.

Hafsi, T. and Turgut, G., 2013. Boardroom diversity and its effect on social performance: Conceptualization and empirical evidence. Journal of business ethics, 112(3), pp.463-479.

Han, S., Jin, J.Y., Kang, T. and Lobo, G., 2014. Managerial ownership and financial analysts' information environment. Journal of Business Finance \& Accounting, 41(3-4), pp.328-362.

Haniffa, R.M. and Cooke, T.E., 2002. Culture, corporate governance and disclosure in Malaysian corporations. Abacus, 38(3), pp.317-349.

Harada, K. and Nguyen, P., 2011. Ownership concentration and dividend policy in Japan. Managerial Finance.

Hsu, C.W., Lien, Y.C. and Chen, H., 2013. International ambidexterity and firm performance in small emerging economies. Journal of World Business, 48(1), pp.58-67.

Initiative, G.R., 2006. Sustainability reporting guidelines, Version 3.0. GRI, Amsterdam.

Initiative, G.R., 2008. Disponível em:< http://www. globalreporting. org >. Acesso em, 11 .

Jaggi, B., Leung, S. and Gul, F., 2009. Family control, board independence and earnings management: Evidence based on Hong Kong firms. Journal of Accounting and Public Policy, 28(4), pp.281-300.

Jamali, D., 2008. A stakeholder approach to corporate social responsibility: A fresh perspective into theory and practice. Journal of business ethics, 82(1), pp.213-231.

Jennifer Ho, L.C. and Taylor, M.E., 2007. An empirical analysis of triple bottom-line reporting and its determinants: evidence from the United States and Japan. Journal of International Financial Management \& Accounting, 18(2), pp.123-150.

Jiang, H., Habib, A. and Hu, B., 2011. Ownership concentration, voluntary disclosures and information asymmetry in New Zealand. The British Accounting Review, 43(1), pp.39-53.

Khan, T., 2006. Company dividends and ownership structure: Evidence from UK panel data. The Economic Journal, 116(510), pp.C172-C189.

Miller, T. and del Carmen Triana, M., 2009. Demographic diversity in the boardroom: Mediators of the board diversity-firm performance relationship. Journal of Management studies, 46(5), pp.755-786.

Milliken, F.J. and Martins, L.L., 1996. Searching for common threads: Understanding the multiple effects of diversity in organizational groups. Academy of management review, 21(2), pp.402-433.

Milne, M.J. and Adler, R.W., 1999. Exploring the reliability of social and environmental disclosures content analysis. Accounting, Auditing \& Accountability Journal, 12(2), pp.237-256.

Nicholson, G.J. and Kiel, G.C., 2004. A framework for diagnosing board effectiveness. Corporate Governance: An International Review, 12(4), pp.442-460.

Nielsen, S. and Huse, M., 2010. The contribution of women on boards of directors: Going beyond the surface. Corporate governance: An international review, 18(2), pp.136-148.

O’Sullivan, M., Percy, M. and Stewart, J., 2008. Australian evidence on corporate governance attributes and their association with forward-looking information in the annual report. Journal of Management \& Governance, 12(1), pp.5-35.

Ong, C.H. and Wan, D., 2008. Three conceptual models of board role performance. Corporate Governance: The international journal of business in society, 8(3), pp.317-329.=

Post, C., Rahman, N. and Rubow, E., 2011. Green governance: Boards of directors' composition and environmental corporate social responsibility. Business \& Society, 50(1), pp.189-223.

Reeb, D.M. and Zhao, W., 2013. Director capital and corporate disclosure quality. Journal of Accounting and Public Policy, 32(4), pp.191-212.

Sanda, A.U., Mikailu, A.S. and Garba, T., 2005. Corporate governance mechanisms and firm financial performance in Nigeria.

Snider, J., Hill, R.P. and Martin, D., 2003. Corporate social responsibility in the 21st century: A view from the world's most successful firms. Journal of Business ethics, 48(2), pp.175-187.

Ullmann, A.A., 1985. Data in search of a theory: A critical examination of the relationships among social performance, social disclosure, and economic performance of US firms. Academy of management review, 10(3), pp.540-557.

Uwuigbe, U., 2011. Corporate environmental reporting practices: A comparative study of Nigerian and South African firms (Doctoral dissertation, Covenant University).

Van der Laan, S., 2009. The role of theory in explaining motivation for corporate social disclosures: Voluntary disclosures vs 'solicited'disclosures. Australasian Accounting, Business and Finance Journal, 3(4), p.2. 
Van der Walt, N. and Ingley, C., 2003. Board dynamics and the influence of professional background, gender and ethnic diversity of directors. Corporate Governance: An International Review, 11(3), pp.218-234.

Van der Walt, N., Ingley, C., Shergill, G.S. and Townsend, A., 2006. Board configuration: are diverse boards better boards?. Corporate Governance: The international journal of business in society, 6(2), pp.129-147.

Wallace, R.S.O. and Cooke, T.E., 1990. The diagnosis and resolution of emerging issues in corporate disclosure practices. Accounting and Business Research, 20(78), pp.143-151.

Wally, S. and Baum, J.R., 1994. Personal and structural determinants of the pace of strategic decision making. Academy of Management journal, 37(4), pp.932-956.

Welford, R., 2007. Corporate governance and corporate social responsibility: issues for Asia. Corporate Social Responsibility and Environmental Management, 14(1), pp.42-51.

Westphal, J.D. and Milton, L.P., 2000. How experience and network ties affect the influence of demographic minorities on corporate boards. Administrative Science Quarterly, 45(2), pp.366-398. 